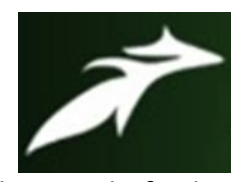

Durga Bhavani Baruku et al, International Journal of Advances in Agricultural Science \& Technology, Vol.8 Issue.11, November-2021, pg. 12-19

ISSN: 2348-1358

Impact Factor: 6.057

NAAS Rating: 3.77

\title{
CONSTRAINTS FACED BY WOMEN IN EMPOWERMENT THROUGH INCOME GENERATING ACTIVITIES IN VISAKHAPATNAM DISTRICT OF ANDHRA PRADESH
}

\author{
Durga Bhavani Baruku ${ }^{1}$; Jahanara²; Dipak Kumar Bose ${ }^{3}$ \\ Research Scholar ${ }^{1}$, Professor and $\mathrm{Head}^{2}$ and Associate Professor ${ }^{3}$ \\ Department of Agricultural Extension and Communication, SHUATS, Allahabad, Uttar Pradesh, India \\ DOI: 10.47856/ijaast.2021.v08i11.002
}

\section{Abstract:}

Women are the builder and moulder of nation's destiny. Though delicate and soft as lily, she has a heart, far stronger and bolder than of man. She is supreme inspiration of man's onward march. Empowerment comes from Women's groups who seek to empower themselves through greater self-reliance. They have right to determine their own choices in life. They also seek to gain control and access to resources. The present study was conducted to find out the "Constraints Faced by Women in Empowerment through Income Generating Activities in Visakhapatnam District of Andhra Pradesh." In Vishakhapatnam District Anakapalli Mandal was selected for data collection. Data was collected from 120 respondents randomly from 6 villages using pre-tested structured interview schedule and analyzed using frequency, percentage, scoring and coefficient of correlation. From this present study the major constraints faced by the respondents are Family restriction, Lack of education, Proper marketing facilities, Lack of proper guidance and financial limitations, Lack of resources, Lack of training and Lack of knowledge, skills and Mismanagement. It was suggested that Family should support to women for participating in different type of income generating activities followed by Women farmers should focus on increasing their education, Govt. should focus on increasing the Proper marketing facilities, Women empowerment organization should focus on proper guidance and different training programmes and Govt. \& private organizations should provide funds for financial supports.

Keywords: Women Farmers, Women Empowerment, Constraints and Suggestions. 


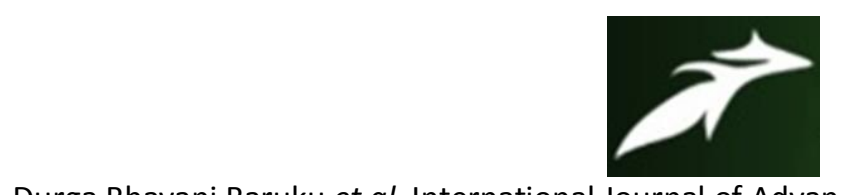

Durga Bhavani Baruku et al, International Journal of Advances in Agricultural Science \& Technology, Vol.8 Issue.11, November-2021, pg. 12-19

ISSN: 2348-1358

Impact Factor: 6.057

NAAS Rating: 3.77

\section{INTRODUCTION}

Empowerment of rural women through income generating activities are considered as those initiatives that affect the economic aspects of people's lives through the use of economic tools such as credit. It is being increasingly realized that women's income in a family is very important in relation to the nutritional, economic and educational Upliftment of the family. Economic independence or access to an inherited or self-generated income is considered as the major means of empowerment of women, to a great extent this is true as economic dependence is the worst form of dependence. To enable women to stand on their own legs, this strategy is attempted and advocated by many governments in this third world. Women's income in a family is very important in relation to their full identity and powers in all spheres of life. The self-help group provides an appropriate platform for initiating and sustaining income generating activities.

Income generating activities will be considered those initiatives that affect the economic aspects of people's lives through use of Economic tools such as credit. Other type of support affecting women's production is considered complementary to income generating activities. For e.g. these might include childcare or basic services provision And Labour saving Technologies. The limits of welfare- oriented response to this growing crisis are now well recognized. Alternatively, many development Agencies are increasing their emphasis on assisting woman to secure income through their own efforts. Such approaches are often categorized as income generating activities and cover initiatives as diverse are thesmall business promotion, Cooperative undertaking job creation scheme, sewing circle, credit and saving groups and youth training programmes.

\section{Objectives:-}

1. To find out the constraints faced by women in empowerment through income generating activities. 


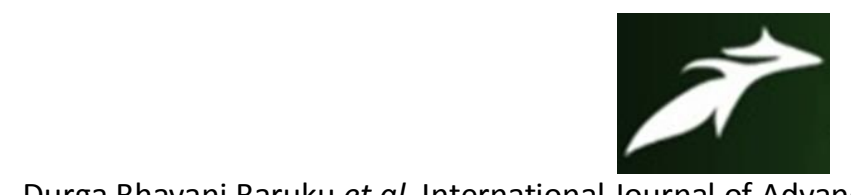

Durga Bhavani Baruku et al, International Journal of Advances in Agricultural Science \& Technology, Vol.8 Issue.11, November-2021, pg. 12-19

ISSN: $2348-1358$

Impact Factor: 6.057

NAAS Rating: 3.77

\section{RESEARCH METHODOLOGY}

This section describes the approaches and methods employed for data collection and analysis. The first sub-section of this chapter presents the description of the study area. Then the details of methodology used to conduct the overall study were discussed in subsequent and sub-sections. Descriptive research design was used for the present study. Descriptive research design is used to describe the characteristics of a population or phenomenon being studies. Vishakhapatnam district of Andhra Pradesh state was selected purposively based on the involvement of maximum women farmers' income generating activities. There were 46 mandals in out of which Anakapalli mandal was selected purposively based on the involvement of maximum women farmers' income generating activities through the help of agricultural officer. There are 25 villages in Anakapalli mandal out of those which six villages were selected purposively based on the involvement of maximum women farmers' income generating activities. 120 numbers of respondents were selected for the present study. Randomly 20 number of farmers were selected from 6 villages with the help of village Sarpanch and agriculture supervisor of respective village (VLW) involvement in agriculture and respondents. The Primary data was collected with the help of personal interview technique, pre-tested structured interview schedule designed especially in the light of objectives setup for the study. The Secondary data was collected from library, journals, books, papers and the documents related to the study. For analyzing data frequency, percentage, scoring and coefficient of correlation were used as statistical tools. They were summarized while qualitative responses were tailed and finally prioritized in order to determine trends and patterns in the data and draw conclusions. It was analyzed on the spot during data collection to avoid missing of relevant information. 




Durga Bhavani Baruku et al, International Journal of Advances in Agricultural Science \& Technology, Vol.8 Issue.11, November-2021, pg. 12-19

ISSN: 2348-1358

Impact Factor: 6.057

NAAS Rating: 3.77

\section{RESULT AND DISCUSSIONS}

Table-1: Socio-economic profile of the respondents

\begin{tabular}{|c|c|c|c|c|}
\hline \multirow{2}{*}{$\begin{array}{l}\text { Sl.no } \\
1 .\end{array}$} & \multicolumn{2}{|c|}{ Socio-economic profile of the respondents } & \multirow{2}{*}{$\begin{array}{l}\text { Frequency } \\
33\end{array}$} & \multirow{2}{*}{$\begin{array}{l}\text { Percentage } \\
27.50\end{array}$} \\
\hline & Age & Low (35 years) & & \\
\hline & & Medium (36-55 years) & 56 & 46.67 \\
\hline & & High (Above 55 years) & 31 & 25.83 \\
\hline \multirow[t]{3}{*}{2.} & \multirow[t]{3}{*}{ Marital status } & Married & 71 & 59.17 \\
\hline & & Un-married & 26 & 21.67 \\
\hline & & Divorced & 23 & 19.16 \\
\hline \multirow[t]{3}{*}{3.} & \multirow[t]{3}{*}{ Religion } & Hindu & 73 & 60.83 \\
\hline & & Muslim & $26 \mathrm{x}$ & 21.67 \\
\hline & & Christian & 21 & 17.5 \\
\hline \multirow[t]{3}{*}{4.} & \multirow[t]{3}{*}{ Caste } & General & 31 & 25.83 \\
\hline & & $\mathrm{OBC}$ & 36 & 30.00 \\
\hline & & SC\& ST & 53 & 44.17 \\
\hline \multirow[t]{3}{*}{5.} & \multirow[t]{3}{*}{ Types of House } & Mud house & 41 & 34.16 \\
\hline & & Semi-cemented & 32 & 26.67 \\
\hline & & Cemented & 47 & 39.17 \\
\hline \multirow[t]{2}{*}{6.} & \multirow[t]{2}{*}{ Family Type } & Nuclear & 79 & 65.83 \\
\hline & & Joint & 41 & 34.17 \\
\hline \multirow[t]{3}{*}{7.} & \multirow[t]{3}{*}{ Family Size } & Small (1-4) & 79 & 65.83 \\
\hline & & Medium(5-8) & 29 & 24.17 \\
\hline & & Large (8above) & 12 & 10.00 \\
\hline \multirow[t]{4}{*}{8.} & \multirow{4}{*}{$\begin{array}{l}\text { Occupation of } \\
\text { Family }\end{array}$} & Agriculture & 27 & 22.50 \\
\hline & & Agriculture + labour & 32 & 26.67 \\
\hline & & Agriculture + business & 41 & 34.16 \\
\hline & & Agriculture + services & 20 & 16.66 \\
\hline \multirow[t]{3}{*}{9.} & \multirow[t]{3}{*}{ Annual Income } & Low (below 50,000) & 29 & 24.17 \\
\hline & & Medium $(50,000-90,000)$ & 51 & 42.5 \\
\hline & & High (Above 90,000) & 40 & 33.33 \\
\hline \multirow[t]{6}{*}{10.} & \multirow[t]{6}{*}{ Education Status } & Illiterate & 13 & 10.83 \\
\hline & & Primary & 25 & 20.83 \\
\hline & & Upper Primary & 26 & 21.67 \\
\hline & & Secondary & 17 & 14.17 \\
\hline & & Higher Secondary & 22 & 18.33 \\
\hline & & Graduate \& Above & 17 & 14.17 \\
\hline 11. & Land Holding & Low (0-5 acre) & 60 & 50.00 \\
\hline
\end{tabular}




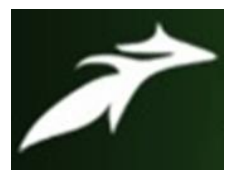

Durga Bhavani Baruku et al, International Journal of Advances in Agricultural Science \& Technology, Vol.8 Issue.11, November-2021, pg. 12-19

ISSN: 2348-1358 Impact Factor: 6.057 NAAS Rating: 3.77

\begin{tabular}{|l|l|l|l|l|}
\hline & & Medium (5-10 acre) & 41 & 34.17 \\
\cline { 3 - 5 } & & High (Above 10 acre) & 19 & 15.83 \\
\hline \multirow{3}{*}{12.} & \multirow{2}{*}{$\begin{array}{l}\text { Mass Media } \\
\text { Exposure }\end{array}$} & Low (4-6) & 27 & 22.50 \\
\cline { 3 - 5 } & & Medium (7-9) & 49 & 40.83 \\
\cline { 3 - 5 } & Sigh (10-12) & 44 & 36.67 \\
\hline \multirow{2}{*}{13.} & \multirow{3}{*}{ Social Participation } & Low (7-11) & 40 & 33.33 \\
\cline { 3 - 5 } & & Medium (12-15) & 47 & 39.17 \\
\cline { 3 - 5 } & & High (16-19) & 33 & 27.5 \\
\hline
\end{tabular}

From the table-1. The results described as followed:

From the above table-1 The data present reveals that majority of the respondents belonged to the medium age group this group alone constitutes 46.67 per cent followed by 59.17per cent of respondents belonged to married in marital status followed by maximum number of respondents belonged to the Hindu religion i.e. 60.83per cent, Majority of the respondents are from Sc \& St caste of 44.17per cent, 39.17per cent of respondents are from cemented type of house followed by 65.83per cent of respondents are from small family size, 65.83per cent of respondents are from nuclear family followed by 34.16 per cent of respondents family occupation is (Agriculture + Business), 42.5per cent of respondents possess medium level of annual income, Majority of the respondents belonged to upper primary level education it constitutes 21.67per cent, 50.00per cent of respondents possess low amount of land holding, 40.83per cent of respondents are from medium level of mass media exposure, 39.17per cent of respondents are from medium level of social participation. 


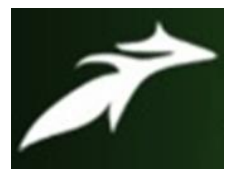

Durga Bhavani Baruku et al, International Journal of Advances in Agricultural Science \& Technology, Vol.8 Issue.11, November-2021, pg. 12-19

ISSN: 2348-1358 Impact Factor: 6.057 NAAS Rating: $\mathbf{3 . 7 7}$

Table -2: Constraints faced by women in empowerment through income generating activities

\begin{tabular}{|c|c|c|c|c|}
\hline \multirow{2}{*}{$\begin{array}{c}\text { Sl. } \\
\text { No. }\end{array}$} & \multirow[t]{2}{*}{ Constraints } & \multicolumn{3}{|c|}{ Response } \\
\hline & & Frequency & Percentage & Rank \\
\hline 1. & Lack of education & 77 & 64.17 & II \\
\hline 2. & Lack of training & 62 & 51.67 & VII \\
\hline 3. & Lack of decision making & 59 & 49.17 & $\mathbf{X}$ \\
\hline 4. & Lack of resources & 63 & 52.5 & VI \\
\hline 5. & Proper marketing facilities & 72 & 60 & III \\
\hline 6. & Lack of proper guidance & 70 & 58.33 & IV \\
\hline 7. & Lack of knowledge and skills & 62 & 51.66 & VIII \\
\hline 8. & Lack of self confidence & 50 & 41.67 & $\mathbf{X V}$ \\
\hline 9. & Family restriction & 90 & 75 & $\mathbf{I}$ \\
\hline 10. & Mismanagement & 60 & 50 & IX \\
\hline 11. & Incapable of taking risks & 51 & 42.5 & XIV \\
\hline 12. & Poor leadership & 58 & 49.17 & $\mathbf{X I}$ \\
\hline 13. & Roles are not sufficient & 41 & 34.17 & XVII \\
\hline 14. & Lack of family support & 42 & 35 & XVI \\
\hline 15. & Non-availability of loans & 53 & 44.17 & XIII \\
\hline
\end{tabular}




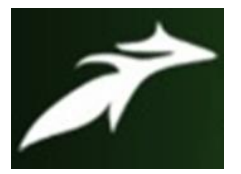

Durga Bhavani Baruku et al, International Journal of Advances in Agricultural Science \& Technology, Vol.8 Issue.11, November-2021, pg. 12-19

ISSN: 2348-1358

Impact Factor: 6.057

NAAS Rating: $\mathbf{3 . 7 7}$

\begin{tabular}{|c|c|c|c|c|}
\hline 16. & Lack of social mobilization & 57 & 47.5 & XII \\
\hline 17. & Financial limitations & 69 & 57.5 & V \\
\hline
\end{tabular}

\section{From the table-2. The results described as followed:}

From this above table-2 represents the constraints faced by the respondents. The topranking constraints is Family restriction $\mathbf{7 5 \%}$ of farmers ( $1^{\text {st }}$ Rank), 64.17 per cent of farmers are facing constraints on Lack of education (II ${ }^{\text {nd }}$ Rank), 60 per cent of farmers are facing constraints on Proper marketing facilities (III ${ }^{\mathrm{rd}}$ rank), 52.5 per cent of farmers are facing constraints on Lack of proper guidance ( $\mathrm{IV}^{\text {th }}$ rank), 57.5 per cent of farmers are facing constraints on Financial limitations ( $\mathrm{V}^{\text {th }}$ rank), 52.5 per cent of farmers are facing constraints on Lack of resources (VI ${ }^{\text {th }}$ rank), 51.67 per cent of farmers are facing constraints on Lack of training $\left(\mathrm{VII}^{\text {th }}\right.$ rank $), 51.66$ per cent of farmers are facing constraints on Lack of knowledge and skills (VIII ${ }^{\text {th }}$ rank), 50 per cent of farmers are facing constraints on Mismanagement (IX ${ }^{\text {th }}$ rank), 49.17 per cent of farmers are facing constraints on Lack of decision making ( $\mathrm{X}^{\text {th }}$ rank), 49.17 per cent of farmers are facing constraints on Poor leadership ( $\mathrm{XI}^{\text {th }}$ rank), 47.5 per cent of farmers are facing constraints on Lack of social mobilization (XII ${ }^{\text {th }}$ rank), 44.17 per cent of farmers are facing constraints on Non-availability of loans (XIII ${ }^{\text {th }}$ rank), 42.5 per cent of farmers are facing constraints on Incapable of taking risks (XIV ${ }^{\text {th }}$ rank), 42.5 per cent of farmers are facing constraints on Lack of self-confidence $\left(\mathrm{XV}^{\text {th }}\right.$ rank), 35 per cent of farmers are facing constraints on Lack of family support (XVI ${ }^{\text {th }}$ rank) and 34.17 per cent of farmers are facing constraints on Roles are not sufficient (XVII ${ }^{\text {Ith }}$ rank). 


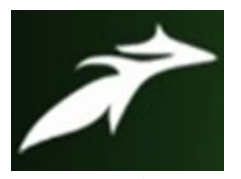

Durga Bhavani Baruku et al, International Journal of Advances in Agricultural Science \& Technology,

Vol.8 Issue.11, November-2021, pg. 12-19

ISSN: 2348-1358

Impact Factor: 6.057

NAAS Rating: 3.77

\section{Suggestion:}

1. Family should support to women for participating in different type of income generating activities.

2. Women farmers should focus on increasing their education,

3. Govt. should focus on increasing the Proper marketing facilities.

4. Women empowerment organization should focus on proper guidance and different training programmes.

5. Govt. \& private organizations should provide funds for financial supports.

\section{CONCLUSION}

It was concluded that the major constraints faced by the respondents are Family restriction, Lack of education, Proper marketing facilities, Lack of proper guidance and financial limitations, Lack of resources, Lack of training and Lack of knowledge, skills and Mismanagement. It was suggested that Family should support to women for participating in different type of income generating activities followed by Women farmers should focus on increasing their education, Govt. should focus on increasing the Proper marketing facilities, Women empowerment organization should focus on proper guidance and different training programmes and Govt.\& private organizations should provide funds for financial supports.

\section{REFERENCES}

[1]. Akter A. and Ahmad N. (2020). Empowering Rural Women's Involvement in Income Generating Activities through BRAC Microfinance Institution in Sylhet District, Bangladesh. International Journal of Academic Research in Business and Social Sciences. 10(11): 146-161.

[2]. Asha K.., Choudhary S. and Khan I.M. (2018). Extent of Empowerment of the Rural Women through. Various Income Generating Activities of Self-Help Groups. International Journal of Current Microbiology and Applied Sciences .7(7):217-224.

[3]. Aysha A., Nobaya A., Mohammad A. I., Wan Munira WJ., Dahlia BZ and Mohammad, MI. (2018). Empowerment Scenario of Rural Women through Income Generating Activities in Bangladesh. Arts and Social Sciences Journal. 9(5). ISSN: 2151-6200.

[4]. Bharathamma G.U., Angadi J.G., Hirevenkanagoudar L.V. and Natikar K.V. (2006). Empowerment of Rural Women through Income Generating Activities. Karnataka J. Agric. Sci., 19(3): 600-602.

[5]. Garima \& Gupta S. (2019). Empowering of rural women through income generating activities. International journal of home science. 5(1):19-21.

[6]. Mittra P.K., Sharmin K.S., Akanda M.G.R. (2017). Empowerment of Rural Women through Income Generating Activities (Decision Making Ability). Imperial Journal of Interdisciplinary Research. 3(6) : 2454-1362.

[7]. Mittra P.K., Sharmin K.S., Akanda M.G.R. and Rashid M.M.O. (2019). Empowerment of Rural Women through Income Generating Activities(Social Participation). International Journals of Sciences and High Technologies. 14(2):318-323. 